\title{
1,25-dihydroxyvitamin D and PTHrP mediated malignant hypercalcemia in a seminoma
}

René Rodríguez-Gutiérrez ${ }^{1,2^{*}}$, Maria Azucena Zapata-Rivera ${ }^{1,2}$, Dania Lizeth Quintanilla-Flores ${ }^{2,3}$, Carlos Rodrigo Camara-Lemarroy ${ }^{2,3}$, Fernando Javier Lavalle-Gonzalez,2, José Gerardo González-González ,2 and Jesús Zacarías Villarreal-Pérez ${ }^{1,2}$

\begin{abstract}
Background: Seminomas have been rarely associated with malignant hypercalcemia. The responsible mechanism of hypercalcemia in this setting has been described to be secondary to 1,25-dihydroxyvitamin D secretion. The relationship with PTHrP has not been determined or studied.

The aim of this study is to describe and discuss the case and the pathophysiological mechanisms involved in a malignant hypercalcemia mediated by 1,25-dihydroxyvitamin D and PTHrP cosecretion in a patient with seminoma.

Case presentation: A 35-year-old man was consulted for assessment and management of severe hypercalcemia related to an abdominal mass. Nausea, polyuria, polydipsia, lethargy and confusion led him to the emergency department. An abdominal and pelvic enhanced $\mathrm{CT}$ confirmed a calcified pelvic mass, along with multiple retroperitoneal lymphadenopathy. Chest $x$-ray revealed "cannon ball" pulmonary metastases. The histopathology result was consistent with a seminoma. Serum calcium was $14.7 \mathrm{mg} / \mathrm{dl}$, PTH was undetectable, 25-dihydroxyvitamin D was within normal values and PTHrP and 1,25-dihydroxyvitamin were elevated $(35.0 \mathrm{pg} / \mathrm{ml}$, and $212 \mathrm{pg} / \mathrm{ml}$, respectively). After the first cycle of chemotherapy with bleomycin, etoposide and cisplatin, normocalcemia was restored. Both PTHrP and 1,25-dihydroxyvitamin D, dropped dramatically to $9.0 \mathrm{pg} / \mathrm{ml}$ and $8.0 \mathrm{pg} / \mathrm{ml}$, respectively.
\end{abstract}

Conclusion: The association of seminoma and malignant hypercalcemia is extremely rare. We describe a case of a patient with a seminoma and malignant hypercalcemia related to paraneoplastic cosecretion of 1,25-dihydroxyvitamin D and PTHrP. After successful chemotherapy, calcium, PTHrP and 1,25-Dihydroxyvitamin D returned to normal values.

Keywords: 1,25-dihydroxyvitamin D, Calcitriol, PTHrP, Malignant hypercalcemia, Seminoma

\section{Background}

Malignant hypercalcemia is the most common paraneoplastic syndrome occurring in $20-30 \%$ of patients with cancer [1]. It usually has an ominous prognosis, with a mortality of $50 \%$ within the next 30 days [2]. Both solid and hematologic malignancies have been associated with this syndrome; the most frequent etiologies being multiple myeloma, lung and breast cancer [3]. Four mechanisms of hypercalcemia in malignancy have been

\footnotetext{
* Correspondence: renerodriguez@investigacion-meduanl.com

${ }^{1}$ Endocrinology Division, Internal Medicine Department, University Hospital

"Dr. José E. González", Ave. Madero y Ave. Gonzalitos s/n, Colonia Mitras Centro, Monterrey, Nuevo León 64460, Mexico

${ }^{2}$ Medical School of the Universidad Autónoma de Nuevo León, Ave. Madero y Ave. Gonzalitos s/n, Colonia Mitras Centro, Monterrey, Nuevo León 64460, Mexico

Full list of author information is available at the end of the article
}

described: local osteolysis, parathyroid hormone relatedprotein (PTHrP) mediated, 1,25-dihydroxyvitamin D (1,25 $(\mathrm{OH})_{2} \mathrm{D}_{3}$, calcitriol) secretion, and ectopic parathyroid hormone (PTH) $[4,5]$.

Seminomas have seldomly been related with hypercalcemia. Less than ten cases have documented this exceptional association. Besides two cases related to bone metastasis, the mechanism of hypercalcemia in seminomas has been discussed in two previous reported cases to be secondary to $1,25(\mathrm{OH})_{2} \mathrm{D}_{3}$ secretion. The underlying mechanism in the rest of the cases was not established. In the previous reports PTHrP was not measured nor related to hypercalcemia. In all of the previous documented cases, independent of the hypercalcemia related mechanism, normocalcemia was achieved soon after definitive treatment was initiated [6-9]. 
Herein, we present a case of a patient with a seminoma and malignant hypercalcemia mediated by 1,25 $(\mathrm{OH})_{2} \mathrm{D}_{3}$ and PTHrP paraneoplastic cosecretion.

\section{Case presentation}

A 35-year-old man was referred to the Endocrinology Division for assessment and management of severe hypercalcemia related to an abdominal mass. Otherwise, he had an unremarkable medical history. One year before admission he noticed a painless hypogastric abdominal mass. The tumor progressively grew and two months before admission he developed asthenia, anorexia, general weakness, constipation, and an unintentional $10 \mathrm{~kg}$ weight loss. A month before admission the appearance of a left inguinal mass finally made him seek medical attention.

An abdominal ultrasound revealed a $10 \times 9 \times 7 \mathrm{~cm}$ heterogeneous (hypoechogenic with hyperechogenic areas) retroperitoneal mass along with bilateral severe hydronephrosis. Serum creatinine was $2.8 \mathrm{mg} / \mathrm{dl}$ with a modification of diet in renal disease (MDRD) calculated glomerular filtration rate (GFR) of $35 \mathrm{ml} / \mathrm{min}$. This consequently led to an uncomplicated unilateral left nephrostomy. An abdominal and pelvic enhanced computed tomography (CT) confirmed a calcified pelvic mass, along with multiple retroperitoneal lymphadenopathy $(>5 \mathrm{~cm}$ each) (Figure 1). A biopsy was performed and the histopathology result was consistent with a seminoma. Chest x-ray revealed "cannon ball" pulmonary metastases. Lactate dehydrogenase (LDH) was $648 \mathrm{UI} / \mathrm{L}$ and human chorionic gonadotropin was slightly elevated $(35.0 \mu \mathrm{UI} / \mathrm{ml})$. Alpha-fetoprotein was within its normal reference value (Table 1 ). A stage IIIB seminoma was

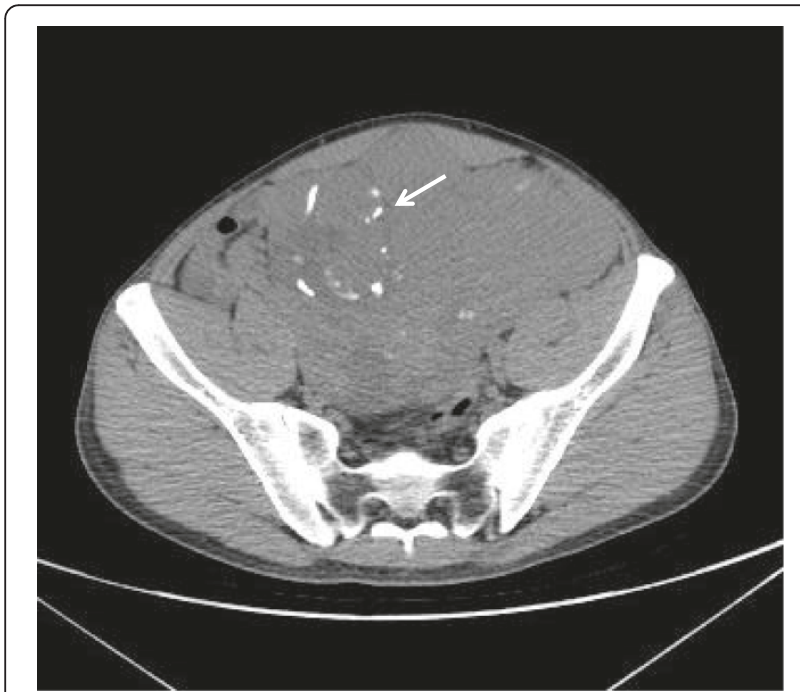

Figure 1 Pelvic enhanced computed tomography that shows a $10 \times 9 \times 7 \mathrm{~cm}$ mass with heterogeneous density and calcifications (Arrow).
Table 1 Laboratory measures

\begin{tabular}{|c|c|c|c|}
\hline Value & Basal & Post-chemotherapy & Range \\
\hline Glucose (mg/dl) & 93 & 87 & $(70-100)$ \\
\hline Creatinine (mg/dl) & 3.7 & 2.8 & $(0.6-1.2)$ \\
\hline Urea nitrogen (mg/dl) & 11 & 13 & $(8-23)$ \\
\hline MDRD GFR (ml/min) & 24.0 & 37.1 & $(\geq 60)$ \\
\hline Albumin (g/dl) & 3.9 & & $(3.5-5.0)$ \\
\hline Calcium (mg/dl) & 14.7 & 9.8 & $(8.2-10.2)$ \\
\hline Phosphorus (pg/ml) & 4.1 & 4.3 & $(2.3-4.7)$ \\
\hline Magnesium (mg/dl) & 1.8 & 2.1 & $(1.5-2.3)$ \\
\hline Potassium (mmol/l) & 3.8 & 4.1 & $(3.5-5.0)$ \\
\hline Urinary calcium (mg/kg/d) & 3.2 & 2.4 & $(2-4)$ \\
\hline Alkaline phosphatase (UI/l) & 146 & & $(50-120)$ \\
\hline $\mathrm{LDH}(\mathrm{UI} / \mathrm{I})$ & 648 & 110 & $(100-200$ \\
\hline AFP $(n g / m l)$ & 4.33 & 3.11 & $(\leq 6.0)$ \\
\hline$\beta-h C G(\mathrm{uUl} / \mathrm{ml})$ & 35.0 & & $(\leq 3.0)$ \\
\hline PTH (pg/ml) & $<3.0$ & 13.2 & $(1.5-37)$ \\
\hline PTHrP (pg/ml) & 35.0 & 9.0 & $(14-27)$ \\
\hline $25(\mathrm{OH}) \mathrm{D}_{3}(\mathrm{ng} / \mathrm{ml})$ & 22.0 & 21.0 & $(>20)$ \\
\hline $1,25(\mathrm{OH})_{2} \mathrm{D}_{3}(\mathrm{pg} / \mathrm{ml})$ & 212.0 & 8.0 & $(18-38)$ \\
\hline
\end{tabular}

MDRD GFR, modification of diet in renal disease glomerular filtration rate; $\mathrm{LDH}$, lactate dehydrogenase; APF, alpha-fetoprotein; $\beta-\mathrm{hCG}$, human chorionic gonadotropin; PTH, parathyroid hormone; PTHrP, parathyroid hormone related protein; $25(\mathrm{OH}) \mathrm{D}_{3}, 25$, Hydroxyvitamin $\mathrm{D} ; 1,25(\mathrm{OH})_{2} \mathrm{D}_{3}, 1,25$-Dihydroxyvitamin $\mathrm{D}$.

diagnosed and the patient was referred to oncology for chemotherapy.

Two days before admission he presented nausea, polyuria, polydipsia, lethargy, and confusion that led him to the emergency room. On physical examination he was hemodynamically stable with a heart rate of 82 per minute, blood pressure of $130 / 85 \mathrm{mmHg}$, a respiratory rate of 16 per minute, a temperature of $36.3^{\circ} \mathrm{C}$ and a roomair oxygen saturation of $97 \%$. An irregular $10 \mathrm{~cm}$ abdominal mass was palpated along with bilateral inguinal adenopathy. The left testicle was not palpable. Serum calcium was $14.7 \mathrm{mg} / \mathrm{dl}$, albumin $3.9 \mathrm{~g} / \mathrm{dl}$, alkaline phosphatase $146 \mathrm{UI} / \mathrm{l}$, creatinine $3.7 \mathrm{mg} / \mathrm{dl}$ with a MDRD GFR of $24 \mathrm{ml} / \mathrm{min}$. He also had a mild elevated aniongap metabolic acidosis and a urinary calcium of $3.2 \mathrm{mg} /$ $\mathrm{kg} / \mathrm{d}$ (240 mg/24 h). Phosphorous, magnesium, potassium, sodium, chlorine, and glucose were normal. PTH was undetectable, 25-dihydroxyvitamin D was normal, PTHrP was $35.0 \mathrm{pg} / \mathrm{ml}$, and calcitriol $212 \mathrm{pg} / \mathrm{ml}$ (Quest Diagnostics Nichols, Chantilly, VA) (Table 1). An electrocardiogram showed a shortened QT interval and a bone scan was negative for metastasis. Calcitonin and hydration with intravenous saline solution at $250 \mathrm{ml} / \mathrm{h}$ was started. Despite therapy, calcium lowered only to $13.5 \mathrm{mg} / \mathrm{dl}$, but nevertheless his mental status improved. The patient received four cycles of bleomycin, etoposide 
and carboplatin. After the first cycle of chemotherapy, calcium, LDH and alkaline phosphatase returned to normal values. Both PTHrP and $1,25(\mathrm{OH})_{2} \mathrm{D}_{3}$ dropped dramatically to $9.0 \mathrm{pg} / \mathrm{ml}$ and to $8.0 \mathrm{pg} / \mathrm{ml}$, respectively (Table 1 ). At 8 months follow-up, the patient was asymptomatic. CT scans showed no residual disease and calcium levels have been consistently normal without medication.

\section{Discussion}

This case illustrates, to our knowledge, the first reported case of malignant hypercalcemia in a patient with seminoma related to paraneoplastic cosecretion of PTHrP and $1,25(\mathrm{OH})_{2} \mathrm{D}_{3}$. Pure seminomas (no non-seminomatous elements present) account for up to $60 \%$ of all testicular germ cell tumors. They usually affect males between the second and fourth decade of life, representing $1 \%$ of all cancers in men. Undescended testes (cryptorchidism), as in our patient, is a risk factor and they are usually associated with a good prognosis with an overall five-year survival of $95 \%$ and even $80 \%$ in intermediate and high-risk patients $[10,11]$. Hyercalcemia associated with malignancy has been well described in both solid and hematologic malignancies (usually lymphomas) and represent the most common cause of elevated serum calcium in hospitalized patients [1]. The four mechanisms by which malignant hypercalcemia can occur are: 1) direct osteolytic metastases (20\% of cases), usually related to multiple myeloma and breast cancer with release of cytokines such as interleukin (IL)-1, IL-6, IL-8 and activation of nuclear factor kappa beta; 2) PTH-rP or humoral hypercalcemia ( $80 \%$ of cases) usually described in nonmetastatic solid tumors (bladder, breast and squamous cell) and some non-Hodgkin lymphomas; 3 ) ectopic PTH secretion with only a few cases reported, and 4) $1,25(\mathrm{OH})_{2} \mathrm{D}_{3}$ secretion that accounts for less than $1 \%$ of cases $[4,5,12,13]$.

Usually associated to granulomatous diseases such as sarcoidosis, tuberculosis, and systemic fungal infections, among others, calcitriol mediated hypercalcemia has been infrequently related to neoplasms [14]. Lymphomas have been the most common type of malignancy described, and other kind of tumors, such as disgerminomas, have rarely been reported [15]. Seminomas have been associated with malignant hypercalcemia almost anecdotally, with less than ten cases reported in the literature (Table 2). King et al. and Metcalfe et al. described the first two cases in the 70s. In their report, they both associated a seminoma with a pseudohyperparathyroidism and were not able to measure neither PTHrP nor vitamin D metabolites. In both cases, hypercalcemia resolved after definitive treatment with orchiectomy or corticosteroid-radiotherapy [6,7]. In 1987, Grote and Hainsworth reported the first case of a seminoma with a calcitriol mediated malignant hypercalcemia. Baseline calcitriol level was $125 \mathrm{pg} / \mathrm{ml}$, with a normal PTH, 25-Hydroxyvitamine D and high $24 \mathrm{~h}$ urine calcium. PTHrP was not measured. After the first chemotherapy cycle, calcitriol concentration fell to $29 \mathrm{pg} /$ $\mathrm{mL}$ and normocalcemia was achieved [8]. In 1992, da Silva et al. reported seven cases (four new and three previously described cases) of seminoma associated with malignant hypercalcemia. With regard to the four new cases, PTH was normal in three and was not measured in one. PTHrP and 25-hydroxyvitamin $\mathrm{D}$ were not measured in any case and $1,25(\mathrm{OH})_{2} \mathrm{D}_{3}$ was measured only in one case with an initial concentration of $79 \mathrm{pg} / \mathrm{mL}$ that decreased to $5 \mathrm{pg} /$ $\mathrm{mL}$ after two cycles of chemotherapy and was associated afterwards with normocalcemia [9].

On the other hand, PTHrP has never been described in a patient with a pure seminoma. There are two reported cases of hypercalcemia associated with non-seminomatous germ cell tumors (NSGCTs). MacDiarmid et al. in 1995 reported a malignant hypercalcemia associated to an extragonadal NSGCT that was suspected to be probably due to a humoral hypercalcemia after bone scans were negative. PTHrP and vitamin D metabolites were not measured [16]. Later on, Sorscher described a patient with severe hypercalcemia and a NSGCT with a high PTHrP and a normal

Table 2 Reported malignant hypercalcemia in seminomas

\begin{tabular}{|c|c|c|c|c|c|c|c|c|}
\hline Author (*) & $\mathrm{Ca}+$ & PTH & PTHrP & $25 D$ & $1,25 \mathrm{D}$ & $T x$ & Ca + after Tx. & Outcome \\
\hline King [6] & 15.4 & NS & NS & NS & NS & Orchiectomy & $\mathrm{NL}$ & NED 10 mo. \\
\hline Metcalfe [7] & 15.8 & NS & NS & NS & NS & $\mathrm{GC}+\mathrm{RT}$ & $\mathrm{NL}$ & NED 8 mo. \\
\hline Grote [8] & 15.4 & 10.0 & NS & 24.0 & 112 & BEP & $\mathrm{NL}$ & NED 2 yr. \\
\hline Da Silva [9] & 12.7 & $\mathrm{NL}$ & NS & NS & NS & $\mathrm{NSCT}$ & $\mathrm{NL}$ & Adenophaty \\
\hline Da Silva [9] & 18.5 & NS & NS & NS & NS & BEP & $\mathrm{NL}$ & NED 2 mo. \\
\hline Da Silva [9] & 20.1 & NS & NS & NS & NS & $\mathrm{NSCT}$ & $\mathrm{NL}$ & NED 4 mo. \\
\hline Da Silva [9] & 16.4 & 0.3 & NS & NS & 79 & BEP & $\mathrm{NL}$ & Improved after $\mathrm{CT}$ \\
\hline This report & 14.7 & $\leq 3.0$ & 35.0 & 22.0 & 212 & BEP & $\mathrm{NL}$ & NED 8 mo. \\
\hline
\end{tabular}

$\left.{ }^{*}\right)$ Reference.

$\mathrm{Ca}+$, Calcium (mg/dl); PTH, parathyroid hormone; PTHrP, parathyroid hormone related protein; 25D, 25, Hydroxyvitamin D; 1,25D, 1,25-Dihydroxyvitamin D; Tx, treatment; NS, not stated; NL, normal; NED, not evidence of disease; BEP, bleomycin, etoposide and cisplatinum; NSCT, not specified chemotherapy;

$\mathrm{CT}$, chemotherapy. 
PTH that returned to normal values after chemotherapy. No measurements of 25-hydroxyvitamin $\mathrm{D}$ and $1,25(\mathrm{OH})_{2}$ $\mathrm{D}_{3}$ levels were made [17]. In our case, a diagnosis of pure seminoma was well documented. Baseline serum calcium was elevated, urinary calcium, phosphorous and 25-hydroxyvitamin D were normal, PTH was undetectable and calcitriol and PTHrP were elevated. After one cycle of chemotherapy, normocalcemia was restored and both, calcitriol and PTHrP dropped to normal levels.

The exact mechanism by which calcitriol is produced in malignancy remains open to debate. Normally, in the kidney, $1 \alpha$-hydroxylase converts 25 -hydroxyvitamin $\mathrm{D}$ into the biologically active $1,25(\mathrm{OH})_{2} \mathrm{D}_{3}$, which is essential for bone and calcium metabolism/homeostasis. Nevertheless, $1 \alpha$-hydroxylase has also been described in normal human tissues such as placenta, skin, gastrointestinal tract, testes, central nervous system and osteoblasts [18]. More than twenty granulomatous conditions are known to have enhanced $1 \alpha$-hydroxylation of vitamin D in macrophages and increased production of active calcitriol causing hypercalcemia and/or hypercalciuria [19]. In lymphomas, Hewison et al., using inmunolocalization, showed stained sections of spleen that were negative for $1 \alpha$-hydroxylase in lymphoma cells, but that were positive in surrounding macrophages [20]. Nonetheless, Evans et al. showed by reverse transcription polymerase chain reaction that mRNA for $1 \alpha$-hydroxylase was increased 222 -fold in disgerminoma cells compared to the surrounding non-ovarian tissue [21]. The exact mechanism in seminomas has not been explored. On the other hand, PTHrP is well recognized to be secreted by a variety of malignancies, in which there is an uncoupling of bone resorption and formation and a reduced ability of the kidney to clear calcium with the resultant hypercalcemia [22]. This last effect on the kidney could be the cause of the normal 24-h urinary calcium reported in our case, when it has been usually reported to be high in other calcitriol mediated pathologies [6-9,23]. As well, PTHrP is usually associated with hypophosphatemia due to an increase in urinary phosphorous; in this case, the concomitant renal failure could have diminished this last effect [24]. Interestingly, normocalcemia has consistently been achieved and sustained, in our case and in all previous cases, soon after definitive treatment with chemotherapy, surgery or glucocorticoids [5-8]. In this way, it is probable that bisphosphonates, denosumab, gallium nitrate, cinacalet and other medications directed to lower serum calcium could be withheld until definitive treatment is initiated.

\section{Conclusion}

Seminomas have seldom been associated with hypercalcemia. We have described the case of a patient with a seminoma and malignant hypercalcemia related to cosecretion of $1,25(\mathrm{OH})_{2} \mathrm{D}_{3}$ and PTHrP. After successful treatment, calcium, PTHrP and $1,25(\mathrm{OH})_{2} \mathrm{D}_{3}$ returned to normal values. The exact mechanism by which seminomas secrete $1,25(\mathrm{OH})_{2} \mathrm{D}_{3}$ still remains to be elucidated.

\section{Consent}

Written informed consent was obtained from the patient for publication of this case report and the accompanying images. A copy of the written consent is available upon request for review by the Journal Editor.

\section{Abbreviations}

PTHrP: Parathyroid hormone related-protein; 1,25( $(\mathrm{OH})_{2} \mathrm{D}_{3}$ : 1,25-dihydroxyvitamin D, calcitriol; PTH: Parathyroid hormone; MDRD GFR: Modification of diet in renal disease calculated glomerular filtration rate; LDH: Lactate dehydrogenase; IL: Interleukin; CT: Computed tomography; NSGCTs: Non-seminomatous germ cell tumors.

\section{Competing interests}

The authors declare that they have no competing interests.

\section{Authors' contributions}

RRG and JGGG served as the principal investigators and led the conception design, acquisition of data, review of literature, and drafted the manuscript. MAZR, DLQF, CRCL contributed in the acquisition of data, review of literature and reviewed the manuscript. FJLG and JZVP contributed the concept of research paper and critically reviewed the manuscript. All authors read and approved the manuscript.

\section{Authors' information}

RRG and MAZR are endocrinology fellows at the Endocrinology Division. DLQF and CRCL are internal medicine residents. FJLG is professor and chief of the diabetes clinic of the Endocrinology Division. JGGG is the vice-dean of research of the Medical School of the Universidad Autonoma de Nuevo Leon and professor of the Endocrinology Division. JZVP is the chief and director of the Endocrinology Division.

\section{Acknowledgments}

We wish to thank Sergio Lozano-Rodriguez for his critical reading of the manuscript.

\section{Author details}

${ }^{1}$ Endocrinology Division, Internal Medicine Department, University Hospital "Dr. José E. González", Ave. Madero y Ave. Gonzalitos s/n, Colonia Mitras Centro, Monterrey, Nuevo León 64460, Mexico. ${ }^{2}$ Medical School of the Universidad Autónoma de Nuevo León, Ave. Madero y Ave. Gonzalitos s/n, Colonia Mitras Centro, Monterrey, Nuevo León 64460, Mexico. ${ }^{3}$ Internal Medicine Department, University Hospital "Dr. José E. González", Monterrey, Nuevo León 64460, Mexico.

Received: 28 September 2013 Accepted: 17 March 2014 Published: 10 April 2014

\section{References}

1. Stewart AF, Broadus AE: Malignancy associated hypercalcemia. In Endocrinology. 5th edition. Edited by DeGroot L, Jameson LJ. Philadelphia: Saunders. in press.

2. Stewart AF: Clinical practice. Hypercalcemia associated with cancer. N Engl J Med 2005, 352(4):373-379.

3. Ralston SH, Gallagher SJ, Patel U, Campbell J, Boyle IT: Cancer-associated hypercalcemia: morbidity and mortality: clinical experience in 126 treated patients. Ann Intern Med 1990, 112:499-504.

4. Horwitz MJ, Stewart AF: Humoral Hypercalcemia Of Malignancy. In Primer On The Metabolic Bone Diseases And Disorders Of Mineral Metabolism. 5th edition. Edited by Favus MF. Washington D.C: American Society for Bone and Mineral Research; 2003:246-250.

5. Roodman GD: Mechanisms of bone metastasis. N Engl J Med 2004, 350:1655-1664.

6. King WW, Cox CE, Boyce WH: Pseudohyperparathyroidism and seminoma. J Urol 1972, 107:809-811. 
7. Metcalfe JB, Carey TC, Barry JM: Genitourinary malignancy and pseudohyperparathyroidism. J Urol 1978, 119:702-704.

8. Grote TH, Hainsworth JD: Hypercalcemia and elevated serum calcitriol in a patient with seminoma. Arch Int Med 1987, 147:2212-2213.

9. da Silva MA, Edmondson JW, Eby C, Loeher PJ: Humoral hypercalcemia in seminomas. Med Pediatr Oncol 1992, 20:38-41.

10. Siegel R, Ward E, Brawley O, Jemal A: Cancer statistics, 2011: the impact of eliminating socioeconomic and racial disparities on premature cancer deaths. CA Cancer J Clin 2011, 61(4):212.

11. Bosl GJ, Motzer RJ: Testicular germ-cell cancer. N Engl J Med 1997, 337(4):242.

12. Doyle MA, Malcolm JC: An unusual case of malignancy- related hypercalcemia. Int J Gen Med 2014, 7:21-27.

13. Kandil E, Noureldine S, Khalek MA, Daroca P, Friedlander P: Ectopic secretion of parathyroid hormone in a neuroendocrine tumor: a case report and review of the literature. Int I Clin Exp Med 2011, 4(3):234-240.

14. Jacobs TP, Bilezikian JP: Clinical review: rare causes of hypercalcemia. J Clin Endocrinol Metab 2005, 90(11):6316.

15. Seymour JF, Gagel RF: Calcitriol: the major humoral mediator of hypercalcemia in Hodgkin's disease and non-Hodgkin's lymphomas. Blood 1993, 82(5):1383.

16. MacDiarmid SA, Norman RW: Extragonadal nonseminomatous germ cell tumour with hypercalcemia, masquerading as renal cell carcinoma: a case report. Can J Surg 1995, 38:80-82.

17. Sorscher S: Elevated parathyroid hormone-related peptide in a patient with an extragonadal germ-cell tumour and hypercalcemia. Can J Surg 2004, 47(2):144. No abstract available.

18. Bikle DD: Extra renal synthesis of 1,25-dihydroxyvitamin $D$ and its health implications. Clinic Rev Bone Miner Metab 2009, 7:114.

19. Hewison M, Burke F, Evans KN, Lammas DA, Sansom DM, Liu P, Modlin RL, Adams JS: Extra-renal 25-hydroxyvitamin D3-1 alpha-hydroxylase in human health and disease. J Steroid Biochem Mol Biol 2007, 103(3-5):316-321.

20. Hewison M, Kantorovich V, Liker HR, Van Herle AJ, Cohan P, Zehnder D, Adams JS: Vitamin D-mediated hypercalcemia in lymphoma: evidence for hormone production by tumor-adjacent macrophages. I Bone Miner Res 2003, 18(3):579-582

21. Evans KN, Taylor H, Zehnder D, Kilby MD, Bulmer JN, Shah F, Adams JS, Hewison M: Increased expression of 25-hydroxyvitamin D-1alphahydroxylase in dysgerminomas: a novel form of humoral hypercalcemia of malignancy. Am J Pathol 2004, 165(3):807-813.

22. Syed MA, Horwitz MJ, Tedesco MB, Garcia-Ocaña A, Wisniewski SR, Stewart AF: Parathyroid hormone-related protein-(1-36) stimulates renal tubular calcium reabsorption in normal human volunteers: implications for the pathogenesis of humoral hypercalcemia of malignancy. J Clin Endocrinol Metab 2001, 86(4):1525-1531.

23. Giannini S, Nobile M, Castrignano R, Pati T, Tasca A, Villi G, Pellegrini F, D'Angelo A: Possible link between vitamin $D$ and hyperoxaluria in patients with renal stone disease. Clin Sci 1993, 84:51-54.

24. Fraher $\amalg$, Hodsman AB, Jonas K, Saunders D, Rose Cl, Henderson JE, Hendy GN, Goltzman D: A comparison of the in vivo biochemical responses to exogenous parathyroid hormone-(1-34) [PTH-(1-34)] and PTH-related peptide-(1-34) in man. J Clin Endocrinol Metab 1992, 75(2):417.

doi:10.1186/1472-6823-14-32

Cite this article as: Rodríguez-Gutiérrez et al.: 1,25-dihydroxyvitamin D and PTHrP mediated malignant hypercalcemia in a seminoma. BMC Endocrine Disorders 2014 14:32.

\section{Submit your next manuscript to BioMed Central and take full advantage of:}

- Convenient online submission

- Thorough peer review

- No space constraints or color figure charges

- Immediate publication on acceptance

- Inclusion in PubMed, CAS, Scopus and Google Scholar

- Research which is freely available for redistribution

Submit your manuscript at www.biomedcentral.com/submit 